\title{
Minor Events and the Risk of Deep Venous Thrombosis
}

\author{
E. M. W. Eekhoff, F. R. Rosendaal', J. P. Vandenbroucke \\ From the Dept of Epidemiology and Haemostasis and Thrombosis Leiden University Medical Center \\ Leiden. The Netherlands
}

\section{Key words}

Venous thromboembolım. eptdemiology, travel, immobilisation. nsk factors, factor $V$

\section{Summary}

Background Deep venous thrombosis is a common disease, with genetic and acquired risk factors Many patients have a history of minor events (short periods of immobilisation such as prolonged travel, short ilness. minor surgery or injuries) before onset of venous thrombosis However, the role of these minor events has received little formal study Also, we do not know how minor events might interact with the presence of genetic prothrombotic defects (tactor V Leiden mutation factor II mutation, proten C S and antithrombin deficiency) Patients and Methods On the basis of case-control data from a thrombosis service in the Netherlands we added a follow-up period for a casecross-over analysis of minor events as nish factors, and a case only analysis tor the interaction with factor $V$ Leiden $A$ total of 187 patients with first. objectively diagnosed venous thrombosis of the legs, aged 15-70, without underlyng malignanues and without major acquired nsk factors entered the study For the analy sis of minor events in the case-cross-over andysis we used a matched odds ratio, in the case only analysis we used the multiphcative sınergy index Results In $326 \%$ of the 187 patients with deep venous thrombosis who did not have major acquired risk factors, minor events were the only external risk factors Minor events increased the rish of thrombosis about 3 -fold as estmated in the case-cross-over analysis (odds ratio $29,95 \%$ confidence interval $15-54$ ) The synergy index between minor events and factor V Leiden mutation in the case-only analysis was 07 (95\% confidence interval 0 3-15) Theretore, persons with factor $V$ Leiden mutation who experience a minor event will have an estimated risk increase of about 17-fold. which exceeds the sum of the individual risk factors Conclusions Minor events are likelv to pldy an important role in the development of deep venous thrombosis, especially in the presence of genetic prothrombotic conditions

\section{Introduction}

The incidence of deep venous thrombosis (DVT) in the general population is estrmated to be 1 per 1000 per year Hereditary coagulation defects that are associuted with an increased nisk are protein $C$, protein S. antithrombin deficiency, factor II (20210 G to A) mutation, and APC resistance (Factor $V$ Letden mutation) (1) Acquired condtions that promote DVT include prolonged immobilisation, major

Correspondence to Prot Dr F R Rosendad MD PhD Dept of Clinıcal Epidemiology, Leiden Universitv Medical Center, P O Box 96002300 RC Letden, The Netherlands - Tel +031 715264037 , Fax +031 715248122. E mall rosendaal@mail medtac leddenuniv nl injunes and surgery The combination of acquired and hereditary nsk factors may lead to the highest nsks In a substantial number ot patients the underlying cause remains unresolved, however

Many patients with DVT. when asked, have a recent history of minor events strain or minor injunes due to effort. short illness or short immobilısation while travelling Since the risk brought about by major surgery and trauma, plaster casts and prolonged immobilisation is substantial, minor illnesses and interventions might prove to be moderate risk factors Nevertheless, minor events have only recerved anecdotal attention in the literature and very little formal study except for (arr) travel (2-4) Our study was performed to investigate the role of minor events in DVT, and therr possible interaction with genetic prothrombotic defects We reanalysed data from the Leiden Thrombophilı Study (LETS) (5) in which minor events, generally occumng within two weeks before the DVT, had been noted in patient discharge letters Firstly, we performed a case cross-over study four years after the first venous thrombosis patients were asked again if thev had expenenced a minor event in a new and arbitrary two week period This permitted us to use the cases as therr own controls Secondly we studied the synergy between minor events and tactor $V$ Leiden in a case only andysis

\section{Methods}

The present studs was an extension of the Leiden Thrombophila Studs (LETS) (5) The LETS study was pertormed between 1988 and 1993 and was a population based case control studv on hereditary venous thrombosts Patients were selected trom the files of the anticoagulant chnics in Leiden Amsterdam and Rotterdam Patsents with known malignant disorders were excluded In total 474 consecuttre outpatients were included (median age 77 ) Patients were referred tor diagnosis after a first objectively confirmed episode of DVT All patients were seen bv one of the mann investigators and completed a standard questionnare Several major acquired thrombosis risk tactors were recorded prolonged immobilisation surgery hospitalisation without surgerv pregnanc and postpartum period Genetic and biochemical rish tactors analvsed initual ly or later on were tactor $V$ Leiden mutation factor II $(20210 \mathrm{~A} / \mathrm{G})$ mutation and deficiencr ot proten $C$ proten $S$ or antuthrombin

Although the LETS questionnaure did not include standard questions for minor events these were reguiarly mentioned as a possible causative tactor Most records trom the patients selected in Leiden contanned both extra comments of the investigutor and hospital discharge letters The records trom Amsterdam and Rotterdam did not have this extra intormation from the discharge letters For our present study, therefore onlv the Letden records were used

We selected pattents without any major acquired risk tactor, only patients without un event or patients with a minor event occurring within two weeks betore the DVT were selected Minor events were defined as bed rest more than $12 \mathrm{~h}$ a day for two or more consecutive days heavy phvsical exer tion minor trauma minor surgery or prolonged travel (by car bus or plane) leading to drmmished or paintul use of one of the extremitues

Two separate analvses were pertormed Firstly to estimate the relative rish of the minor event itselt we applied a case-crossover study, using the cases of this study as therr own control This was accomplished durng the tollow-up of 
these pattents, on average four years after the intual inclusion: patients were asked if a minor event had occurred in the arbitrary two weeks pertod before they had been approached for this follow-up The follow-up was by questuonnare, augmented by telephone inquines: patients could indicate on the questionnaure whether any minor event had happened recently, and they were subsequently phoned to ask the detals and time window of these minor events Of each pattent we therefore knew not only whether he or she had expenenced a minor event in the (approxımately) two weeks before the DVT, but also in an arbitrary two week penod at another tume in their life This permits a matched case-control analysis to see how much more frequent such events are in the weeks preceding DVT than in another period in the same patients life

Secondly, the minor events preceding the onginal venous thrombosis were studied in their combination with the presence of factor V Leiden The extent of interaction between the exposure of minor events and the presence of Factor $\mathrm{V}$ Leiden on the rish for thrombosis was assessed by a case-only study $(6,7,8)$ The case-only study relies on the assumption that the two factors of interest are independently distributed in the general population That is a reasonable assumption for genetic risk factors and minor events for minor events that precede a first DVT in a patient it is likely that their occurrence, $1 \mathrm{e}$ whether or not the patient engaged in plane travel before a first DVT, was not influenced by the presence or absence of a hitherto unknown genetic factor (factor $V$ Leiden and the prothrohbin mutation was unknown at the time of our original investigation) DVT cases are divided into those with and without minor events The odds ratio of the tactor $V$ Leiden is then an estimate of the synergy index on the multiplicative scale This synergy index is the factor by which the joint relature risks of genetic defects and minor events have to be multiphed

\section{Results}

We included 271 patients from the Leiden part of the LETS study The male/female ratio was 120/151, with mean age at diagnosis of the thrombosis +2 years (range 15-69, SD 14) Of the 271 patients 84 were excluded because of pregnancy or postpartum. major operations, prolonged immobilisation (more than two weeks), or hospital stay for more than three days preceding their DVT

Of the remainng 187 patients. 61 had experienced minor events (32 6\%), the other 126 patients had no recorded event Table 1 shows the male/female ratio. mean age and range of the cases with and without minor events

Table 2 summanses the characteristics of the minor events The majonty was bed rest at home for various conditions, including minor

Tuble 1 Sex and age characteristics of the 187 patients included in the study

\begin{tabular}{llll}
\hline & male:female & mean age \pm SD & range \\
\hline minor events $(n=61)$ & 3130 & $433 \pm 134$ & $146-687$ \\
no minor events $(n=126)$ & 5571 & $428 \pm 146$ & $153-673$
\end{tabular}

Tuble 2 Characteristics of the minor events preceding DVT

\begin{tabular}{lll}
\hline Minor event & Patients & Remark \\
\hline $\begin{array}{l}\text { Travel } \\
\text { Rest at home > 12 h }\end{array}$ & 11 & $\begin{array}{l}\text { car 6, plane 3, bus 1, otherwise 1 } \\
\text { hernia 6, malaise 6, infection 2, } \\
\text { trauma 10, heavy physical exer- } \\
\text { tion 12 } \\
\text { arthroscopy 6, menuscectomy 2, } \\
\text { excision ganghon/pin knee 2, ex- } \\
\text { cision exostosis 1, scierosing of } \\
\text { varices 1, coronary angiography 1, } \\
\text { other 1 }\end{array}$ \\
\hline
\end{tabular}

Table 3 Coagulation abnormalites at time of deep venous thrombosis

\begin{tabular}{lcc}
\hline Coagulation abnormality & $\begin{array}{c}\text { with minor event } \\
(n=61)\end{array}$ & $\begin{array}{c}\text { no event } \\
(n=126)\end{array}$ \\
\hline protein C & 1 & 7 \\
protein S & 2 & 2 \\
FV Leiden AG & 9 & 22 \\
FV Leiden AA & - & 3 \\
Factor II (20210 A) & - & 6 \\
\hline
\end{tabular}

Table + Results of the case cross-over studv

\begin{tabular}{lccr}
\hline Minor Events & present before DVT & absent beiore DVT & \\
\hline $\begin{array}{l}\text { present in recent period } \\
\text { absent in recent period }\end{array}$ & 9 & 12 & 21 \\
& 35 & 72 & 107 \\
\hline & 44 & 84 & 128 \\
\hline
\end{tabular}

injuries Travel and minor surgery had lesser contrubutions The median interval between the events and the thrombosis was 2 days (range 0 -14) The median time of the duration of the minor event was 1 day (range 1-14 days)

Coagulation abnormalittes are summarised in Table 3 In 12 of the 61 patients (20\%) with a minor event, a hereditory abnormality of coagulation was found ( 9 patients had a factor $V$ Leiden) In the patients without minor events, 40 of the 126 pattents (30\%) had a coagulation abnormality ( 25 factor $V$ Leiden) Note that 3 patents who were homozygotes for factor $\mathrm{V}$ Leiden and most of the patients with a proten $\mathrm{C}$ deficiency were found in the patient group without minor erents

The case-cross-over study that was pertormed at approximately four years after the initial event. dunng a follow-up investigation. is presented in Table 4 Of the 187 patients, 128 could be included Several reasons existed for the exclusion of the 59 patients, ranging from pregnancy, nontraceability major medical erents or unwillingness to participate Of these 128 patients. 21 had expenenced a minor event durng the recent two week penod preceding the time of follow-up The matched andlysis of the presence or absence of minor events is presented in Table 4 The matched odds-ratio as an estumate of the relative nsk. is 29 (confidence interval 1554 )

We can restrict the case-cross-over andlysis in Table 4 to those without factor $V$ Leiden, in order to measure the independent effect of minor events Twenty of the 128 patients carmed factor $V$ Leiden all were among those without a recent minor event ( 6 of 35 and 14 of 72) The matched odds ratio without these patients became 24 , which is

Table 5 Charactertstics of the minor events in case cross-over study

\begin{tabular}{|c|c|c|c|}
\hline Recent minor event & Patıents & $\begin{array}{l}\text { Type of recent event } \\
\qquad(n=21)\end{array}$ & $\begin{array}{l}\text { Minor event at ornginal } \\
\text { DVT } \quad(n=9)\end{array}$ \\
\hline Travel & 5 & $\begin{array}{l}\text { car } 2 \\
\text { plane } 2 \\
\text { bus } 1\end{array}$ & $\begin{array}{l}\text { - } \quad \text { plane l } \\
\text { - } \quad \text { car } 1\end{array}$ \\
\hline Rest at home $>12 \mathrm{~h}$ & 15 & $\begin{array}{l}\text { hernia } 3 \\
\text { maiaise } 5 \\
\text { infection } 4 \\
\text { trauma } 3\end{array}$ & $\begin{array}{ll}- & \text { malatse } 1 \\
- & \text { trauma } 2 \\
- & \text { heavy physical } \\
\text { exertion } 2 \\
\text { hernia! }\end{array}$ \\
\hline Mınor surgery & 1 & other I & car 1 \\
\hline
\end{tabular}


Table 6 Results of the case-only study

\begin{tabular}{cccc}
\hline Minor events & FV Leiden + & FV Leiden - & \\
\hline+ & 9 & 52 & 61 \\
- & 25 & 101 & 126 \\
& 34 & 153 & 187 \\
\hline
\end{tabular}

sufficiently close to the overall estımate of 29 , given the small numbers

The type of minor events durng the more recent two week period is presented in Table 5, together with the onginal minor event of the same groups of patients Conspicuously absent from the list of recent minor events in comparison with the ones preceding DVT is minor surgery The relative risk for minor surgery would therefore be very high

The synergy index of the interaction between minor events and factor $V$ Leiden was obtained by a case-only analysis on the original data of DVT $1 \mathrm{e}$, the minor events preceding DVT and factor $V$ Leiden DNA determinations In an analysis on Table 6, the odds-ratıo. estımating the synergy index, is 069 with a confidence interval of 0315 , which indicates the presence of an incomplete multiplicative effect of about 07

\section{Discussion}

Our results support the hypothesis that minor events play an important role in the cause of renous thrombosis To estimate the separate effect of minor events, we used a case-cross-over study in which the cases were their own controls Four years after the venous thrombosis, patients were asked again if they had expenenced minor events in an arbitrary two-week period This yielded a close to 3-fold increase in risk of venous thrombosis after minor events In addition we calculated a synergy index of about 07 between small events and factor $V$ Leiden If we take the independent nsk elevation of factor $V$ Leiden to be 8 -fold this means that the overall relative risk of a minor event in a person who carries the factor $V$ Leiden mutation will be 8 tumes 3 tumes 07 , which amounts to a relative risk of about 17 That joint relatıve risk is clearly higher than the effect of each nusk factor alone, and exceeds the sum of the relative risks

Before accepting these estımates at face value, we have to acknowledge potential strengths and weaknesses in our desıgn The original LETS study was not designed for the aim of this investigation, the association with minor events, however, was spontaneously noticed by the physician or investigator One third of the patients had a minor event in the weeks preceding their DVT, which is a remarkable amount This confirms the overall impression of physicians that patients often volunteer a history of minor events To study how high the frequency really is, we used the patients as therr own controls, and asked them about similar minor events dunng an arbitrary 2 week penod at the occasion of a four year follow-up investigation Since it is possible that the original spontaneous recording by physicians was elicited by some in-depth probing of the patıents, we also probed rather in-depth durng the follow-up patients could indicate on a questionnaire whether any of the small events had been happening recently, and they were subsequently phoned to ask the details and tume window of these small events. Of course, our study is possibiy hampered by the increased age and consequent changes in life habits of the patsents. We did not obtain follow up on all patıents, although we do think it unlikely that participation in the follow-up would be associated with the expenence of a minor event Nevertheless, a bias could also be introduced in the patient group due to their familanty with the possible nsk of minor events

A number of studies with a few cases tends to support the hypothesis that minor events play a significant role in DVT We found at least twenty reports in the literature that studied the relation of thromboembolism and minor events, published between 1940 and 1998 (9-29) Most papers were descriptions of cases or case series and concerned pulmonary embolism, some with detectable DVT, manly associated with alr travel During air travel cabin related risk factors leading to hypercoagulability and hypoxia are postulated to increase the risk to develop DVT due to stasis Only few papers also described the assocration with other traffic (car, train, ship), immobilisation in theatre/ cinema, or due to effort, strain or cramped conditions in sheiters (among others 9 21, 24 27) There were few relevant larger studies One retrospective case series identified 44 patients with DVT related to alr flight (from a larger retrospective senes of 254 persons), of which a minonty without known risk factors, but also some with injury to the lower extremity pnor to travel (20) A recent formal case-control study with 160 cases and the same number of controls, investigating all modes of travel and going back several weeks in the history of the patient, found that $245 \%$ of patients and $75 \%$ of controls had a history of travel of more than five hours, leading to a fourfold increase in nsk (4)

In our study the jount effect of factor $V$ Ledden and minor events was shown to be high, at a 17 fold increase in risk of the combination This means that additional cases of DVT occur due to the synergy of minor events and factor V Leiden, which would otherw ise not have occurred by either nish factor alone One should also bear in mind that several risk factors might enhance each other, $\mathrm{eg}$ factor $\mathrm{V}$ Leiden, minor events and oral contraceptive use In a recent study in patients taking oral contraceptives who developed deep-vein thrombosis or pulmonary embolism, the factor $V$ Leiden and acquired rish factors (both minor and major events) were both found to be multiplicative risk factors over and beyond oral contraceptive use (30) Unfortunately, the relative contribution of minor and major events could not be estimated from that study These results are important, since a recent epıdemic of pulmonary embolism deaths with third generation contraceptives in New Zealand concerned a number of women who had expenenced minor events durng use of these contraceptivesi (31) Rather than blaming the minor events. it becomes increasingly clear from our study and several others that the concomitant use of more thrombogenic contraceptives leads to the heıghtened risk $(32,33)$

In conclusion, our study confirms the clinical notion that minor events are likely to play a role in the etrology of DVT, especially in the presence of hereditory thrombogenic risk factors

\section{Achnowledgement}

We acknowledge the great help of the pattents who volunteered for the initial study and the follow-up examination We also ach nowledge the efforts of Dr T Koster and of our data-managers Ms W Noteboom and Ms A Schrejer in organising the initral study and the follow-up The original study was supported by a grant from the Netherlands Heart Foundation

\section{References}

1 Lane DA, Mannuccı PM. Bauer KA. Beruna RM, Bochkov NP, Boulyjenkov V, Chandy M, Dahlback B, Ginter EK, Miletch JP, Rosendaal FR, Seligsohn U Inhented thrombophilia Part 1 Thromb Haemost 1996, 76 $651-62$ 
2 Houghton A. Taylor P Vascular hazards of ar travel Brush J Clın Practice 1993, 47 60-1

3 Milne $R$ Venous thromboembolism and travel is there an association J R Coll Physicians Lond 1992, 1 47-9

4 Ferran E. Chevalher Th, Chapelier A, Baudouy M Travel as a nsk factor for venous thromboembolic disease Chest 1999, 115 440-4

5 Koster T, Rosendaal FR, de Ronde H, Bret E, Vandenbroucke JP, Bertuna RM Venous thrombosis due to poor anticoagulant response to activated proten C Leiden Thrombophilia Study Lancet 1993, 34215036

6 Begg CB Zhang ZF Statıstical analysis of molecular epidemology studies employing case sentes Cancer Epidemiology Biomarkers \& Prevention 1994, 3 173-5

7 Khoury MJ. Flanders WD Nontraditional epidemılogic approaches in the analysis of gene environment interaction case control studies with no controls' Am J Epidemiol 1996, 14t 207-13

8 Piegorsch WW, Weinberg CR Taylor JA Non-hierarchical logistic models and case only designs for assessing susceptibility in population-based case control studies Statistics in Medicine 199413 153-62

9 Benott R Traveller thromboembolic disease the economy class syndrome J Mal Vasc 199217 B84-7

10 Beıghton PH, Richards PR Cardıovascular disease in air travellers Bnt Heart J 196830367 .

11 Sarvesvaran R Sudden natural deaths associated with commercial air travel Med Sci Law 198626 35-8

12 Paganin F Laurent Y Gauzere BA Blanc P Roblin X Pulmonary embo lism on non-stop flights between France and reunion island Lancet 1996 34711956

13 Lederman JA, Keshavarzian A Acute pulmonary embolism following air travel Postgr Med J 198359 104-5

14 Marshall M Flugressen-Thrombose Munch Med Wochenschr 1982, 124 83

15 Finch $\mathrm{P}$ Ransford $\mathrm{R}$, Hill Smith A Thromboembolism and air travel Lancet 1988 ॥ 1025

16 Holliday J Atypical presentation of multiple puimonary emboli in a young traveller J R Coll Gen Pract 198535497

17 Homans T Thrombosis of the deep leg veins due to prolonged sitting New Engl J Med $196+250 \quad 148-9$

18 Black J Deep-vein thrombosis and pulmonarv embolsm Lancet 1993 3423523
19 Cruickshank JM, Gorlın R, Jennett B AIr travel and thrombotic epısodes the economy class syndrome Lancet 1988, $11497-8$

20 Kistner RL, Eklof BO, Masuda EM, Sonntag BV, Wong HP Venous thromboembolism in association with prolonged ar travel Dermatology Surgery 1996, 22 637-41

21 Simpson K Shelter deaths from pulmonary embolısm Lancet $194027+4$

22 Steinhauser RP, Stewart JC Deep venous thrombosis in the military pilot Aviat Spac Environ $198960 \quad 1096-8$

23 Symington IS Stack BHR Pulmonary thromboembolism after travel $\mathrm{Br} J$ Dis Chest 1977, 71 138-40

24 Crane $C$ Deep venous thrombosis in leg following effort strain New Engl J Med 1952, $246529-33$

25 Carrns NJW, Thomas JEP Abson CP Pulmonary embolısm a hazard of air travel Cent Afr J Med $198127 \quad 85-87 \quad 1981$

26 Burkı U Lungenembolten ber und nach Lang-Streckenflugen (economy class syndrome) Schwelz Med Wochenschrift 1989, 119 287-9

27 Medler RG McQueen DA Effort thrombosis in a young wrestler J Bone Joint Surgery 19937510713

28 O'Donnell D Thromboembolism and arr travel Lancet 1988 11 797

29 Mercer A, Brown JD Venous thromboembolism associated with air travel a report of 33 patıents Avration Space and Environmental Medicine $199869 \quad 154-7$

30 Schambeck C Schwender S Haubitz I Geisen UE Grossmann RE Keller $F$ Selective screening tor the Factor V Lerden mutation is it advisable prior to the prescription of oral contraceptives? Thromb Haemost 199778 1480-3

31 Medicines Adverse Reaction Committee of New Zealand URL www medsate govt nz/hprots htm', go to Medicines Safety', Third generation contraceptives and pulmonary embolısm December 1998 and February 1999

32 WHO Scientific Group Cardiovascular Disease and Sterold Hormone Contraception WHO Technical Report Series 877 WHO Genera 1998

33 Walker AM Newer oral contraceptives and the risk of renous thrombo embolısm Concraception 199857 169-81

Recenved Junc 231999 Accepted atter revision October 281999 